\title{
A new vent-related foraminifer from the Lower Toarcian black claystone of the Tatra Mountains, Poland
}

Jarosław Tyszka, Renata Jach, and Miroslav Bubík

Acta Palaeontologica Polonica 55 (2), 2010: 333-342 doi: http://dx.doi.org/10.4202/app.2009.0082

Recurvoides infernus sp. nov., one of the oldest representatives of the superfamily Recurvoidacea (Foraminifera), is described from a thin black claystone overlying the manganese deposits of the Krížna Unit in the Western Tatra Mountains (Poland). These manganese carbonates/silicates were laid down around a shallow-water exhalative submarine hydrothermal vent that was active in the early Toarcian. The microfossils are possibly the first described Jurassic foraminifera associated with hydrothermal vents. The assemblage is characterized by a high abundance and dominance of this new species. The primary lamination of the black claystone, the lack of any macrofauna, and an elevated TOC content point to oxygen-deficient conditions during sedimentation of these deposits. Furthermore, the nearly exclusive occurrence of agglutinated foraminifers suggests a low $\mathrm{pH}$ level. It is likely that the foraminifers colonized vent-related bacterial mats which acted as a rich and stable food source. Modern shallow- and deep-water hydrothermal vents may represent similar habitats.

Key words: Foraminifera, Ammosphaeroidinidae, agglutinated foraminifera, hydrothermal vent, black claystone, suboxia, the Carpathians, Tethys, Jurassic.

Jarosław Tyszka [ndtyszka@cyf-kr.edu.pl], Institute of Geological Sciences, Polish Academy of Sciences, Cracow Research Centre, Senacka 1, PL31-002

Kraków, Poland; Renata Jach [renata.jach@uj.edu.pl], Institute of Geological Sciences, Jagiellonian University, Oleandry 2a, PL30-063 Kraków, Poland; Miroslav Bubík [miroslav.bubik@ geology.cz], Czech Geological Survey, Leitnerova 22, 65869 Brno, Czech Republic.

This is an open-access article distributed under the terms of the Creative Commons Attribution License (for details please see creativecommons.org), which permits unrestricted use, distribution, and reproduction in any medium, provided the original author and source are credited. 
FoF Full text $(481.2 \mathrm{kB})$ 